\title{
Analisis Vacuum Consolidation pada Perbaikan Tanah Lempung Lunak dengan Model Axisymmetric
}

\author{
NADYA UTAMI RIVANGA, INDRA NOER HAMDHAN \\ Jurusan Teknik Sipil, Institut Teknologi Nasional, Bandung \\ Email: utamirivanga@gmail.com
}

\begin{abstract}
ABSTRAK
Tanah lempung lunak merupakan jenis tanah yang memiliki kuat geser yang kecil, koefisien permeabilitas yang kecil, kompresibilitas yang besar, dan mempunyai daya dukung rendah. Kondisi tersebut menyebabkan tanah lempung lunak menjadi tantangan pada kontruksi yang akan di bangun diatasnya, sehingga diperlukan perbaikan tanah. Salah satu perbaikan tanah untuk tanah lempung lunak yang banyak dijumpai yaitu vertical drain dan preloading. Pada penelitian ini metode tersebut akan dikombinasikan dengan vacuum consolidation. Tegangan vakum yang digunakan pada kasus ini sebesar 50 dan $80 \mathrm{kPa}$. Analisis yang dilakukan dengan menggunakan program PLAXIS 2D dengan model Axisymmetric. Analisis dilakukan dengan memvariasikan tiga dari sekian banyak soil model yaitu Mohr Coulomb, Hardening Soil, dan Soft Soil. Berdasarkan hasil dari penelitian nilai penurunan, tegangan pori, dan waktu konsolidasi yang dihasilkan berbeda tetapi hasil penurunan soil model dengan Hardening Soil dan Soft Soil tidak terlalu berdeda secara signifikan.
\end{abstract}

Kata Kunci: tanah lempung lunak, vacuum consolidation, Mohr Coulomb, Hardening Soil, Soft Soil, axisymmetric, PLAXIS 2D

\begin{abstract}
Soft clay is a type of soil that has low shear strength, high compressibility, low coeffiecient of permeability and low bearing capacity. The condition caused soft clay soil to be a challenge on the construction that will be built on it, so that it needed soil improvement. The soil improvement for soft clay that often found is vertical drain and preloading. In this final project that method will be combined with vacuum consolidation. The vacuum pressure used in this case amount from 50 and $80 \mathrm{kPa}$. The analysis was performed using PLAXIS 2D program with Axisymmetric model. The analysis was done by varying the three of soil models Mohr Coulomb, Hardening Soil, and Soft Soil. Based on the settlement of the research, settlement value, pore pressure, and time of consolidation are different but the result of soil models of Hardening Soil and Soft Soil is not significantly differentiated.
\end{abstract}

Keywords: soft clay, vacuum consolidation, Mohr Coulomb, Hardening Soil, Soft Soil, axisymmetric, PLAXIS 2D 


\section{Pendahuluan}

\subsection{Latar Belakang}

Pada saat ini pembangunan di Indonesia semakin maju, banyak gedung-gedung pencakar langit dan juga fasilitas umum yang sedang dibangun. Namun karena keterbatasan lahan yang ada sekarang banyak pembangunan dilakukan didaerah tanah yang kurang baik. Salah satunya jenis tanah lunak yang relatif memiliki daya dukung yang relatif rendah.Keadaan tanah seperti itu bisa diatasi dengan melakukan perbaikan tanah pada lokasi tanah yang lunak ini.

Pada penelitian ini metode perbaikan tanah yang dilakukan dengan membuat timbunan (preloading) di atas tanah lempung lunak yang ada dengan tambahan pemasangan Prefabricated Vertical Drains (PVD) dan dikombinasikan dengan vacuum consolidation. Penelitian ini menggunakan aplikasi PLAXIS 2D. Anilisis dilakukan dengan memvariasikan memvariasikan kapasitas vacuum dan juga menganalisis dengan beberapa soil model yaitu Mohr Coulomb, Hardening Soil dan Soft Soil.

Penelitian ini bertujuan untuk menganalisis kinerja proses konsolidasi dari metode perbaikan tanah dengan timbunan (preloading) dan Prefabricated Vertical Drains (PVD) dengan vacuum maupun tanpa vacuum. Analisis dilakukan menggunakan PLAXIS 2D dengan model axisymmetric dengan memvariasikan kapasitas vacuum dan juga menganalisis dengan beberapa soil model yaitu Mohr Coulomb, Hardening Soil dan Soft Soil. Manfaat penelitian ini diharapkan bisa mengetahui efektifitas waktu dari penurunan menggunakan timbunan dengan PVD dan bantuan dari vacuum.

\section{KAJIAN PUSTAKA}

\subsection{Perbaikan Metode Perbaikan Tanah dengan Metode Prefabricated Vertical Drains (PVD) dengan kombinasi prealoding}

Preloading pada tanah lempung lunak dengan vertical drains adalah salah satu metode populer yang digunakan untuk meningkatkan kekuatan geser tanah lunak dan mengendalikan penurunan pasca konstruksi. Karena permeabilitas tanah sangat rendah, waktu konsolidasi untuk mencapai penurunan yang diinginkan atau kekuatan geser yang diinginkan mungkin akan memakan waktu yang lama (Indraratna et. al., 2010).

Prefabricated Vertical Drains ini yaitu dengan menancapkannya pada tanah yang akan dibebani dengan preloading, sehingga terjadi proses penurunan karena kandungan air tanah yang keluar melewati PVD. Pemasangan PVD ini memiliki pola pemasangan yang berbentuk segitiga atau persegi panjang. Berikut ini merupakan persamaan dari Hansbo untuk mencari ekuivalen diameter dari PVD ditunjukan Persamaan 1.

$$
d_{w}=\frac{2(w+t)}{\pi}
$$

halmana:

$d_{w}=$ diameter PVD ekuivalen $(\mathrm{m})$,

$\mathrm{w}=$ lebar dari PVD $(\mathrm{m})$,

$t \quad=$ ketebalan dari PVD (m). 


\subsection{Metode Vacuum Consolidation}

Vacuum Consolidation merupakan metode perbaikan tanah dengan memasangkan pompa pada salularan yang akan disambungkan pada PVD. Menurut Dam et al. (2006), metode ini didasarkan pada gagasan menerapkan pengisapan vakum ke massa tanah yang terisolasi, mengurangi tekanan atmosfir di dalamnya, sehingga dengan mengurangi tekanan air pori di tanah sehingga tegangan efektif meningkat tanpa mengubah tegangan total. Berikut ini merupakan digram metode vakum yang ditunjukan Gambar 1.

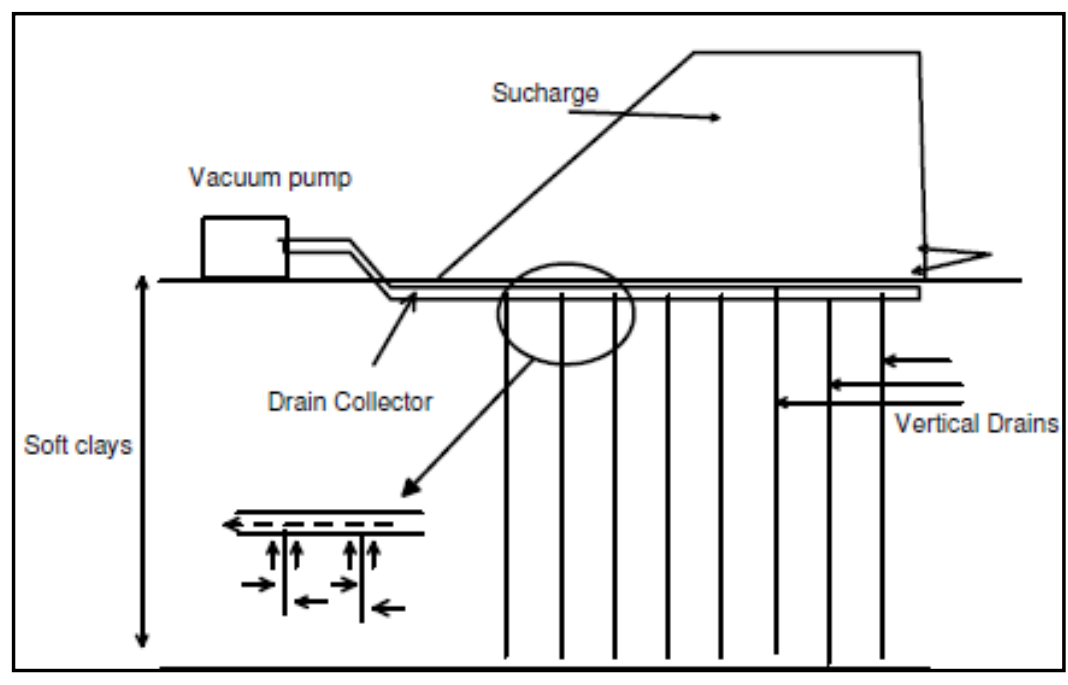

Gambar 1. Diagram metode vakum

(Sumber: Indraratna, 2009)

\subsection{Penurunan Konsolidasi}

Konsolidasi adalah proses mengecilnya volume pada tanah yang jenuh secara perlahan, proses tersebut berlangsung terus-menerus akibat mengalirnya sebagian air pori pada tanah yang jenuh. Das (1985) menjelaskan bahwa penurunan pada tanah yang disebabkan oleh pembebanan dapat dibagi ke dalam dua kelompok besar, yaitu:

1. Penurunan konsolidasi (consolidation settlement), yang merupakan hasil dari perubahan volume tanah jenuh air sebagai akibat dari keluarnya air yang menempati pori-pori tanah.

2. Penurunan segera (immediately settlement), yang merupakan akibat dari deformasi elastis tanah kering, basah, dan jenuh air tanpa adanya perubahan kadar air. Perhitungan penurunan segera umumnya didasarkan pada penurunan yang diturunkan dari teori elastisitas.

\subsection{PLAXIS 2D}

PLAXIS adalah program komputer yang dapat digunakan untuk menganalisa deformasi, aliran air tanah, dan konsolidasi. Pemodelan dapat dilakuan secara plane strain maupun axisymmetric. Model axisymmetric digunakan untuk struktur berbentuk lingkaran dengan penampang melintang radial yang kurang lebih seragam dan kondisi pembebanan mengililingi sumbu aksial, dimana deformasi dan kondisi tegangan diasumsikan sama di setiap arah radial. Seperti Gambar 2 yang menunjukan model axisymmetric. 


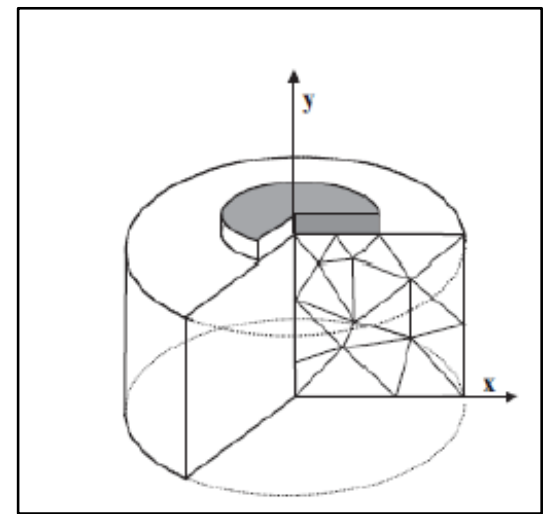

Gambar 2. Model axisymmetric (Sumber: PLAXIS 2D)

\subsection{Model Tanah}

Pemodelan tanah pada PLAXIS 2D terbagi menjadi beberapa model seperti Mohr Coulomb, Hardening Soil dan Soft Soil. Model tanah ini menganalisis suatu material dan mengetahui perilaku tanah.

1. Model Mohr Coulomb

Model Mohr Coulomb yang diaplikasikan pada PLAXIS 2D akan menghasilkan prediksi dilatansi yang berlebihan. Karena itu, selain fungsi kelelehan (yield function) digunakan juga sebuah fungsi potensial plastis (plastic potential plastic, g) yang besarnya tidak sama dengan fungsi kelelehan tersebut dan dinyatakan sebagai non associated plasticity.

2. Model Hardening Soil

Model Hardening Soil merupakan advanced model yang dapat digunakan untuk memodelkan berbagai jenis perilaku tanah dan batuan. Perbedaan utama antara model Hardening Soil dan Mohr Coulomb menjelaskan pembatasan nilai tegangan berdasarkan nilai sudut geser sedangkan model Hardening Soil menjelaskan jenis elastoplastis dari model hiperbolik.

3. Model Soft Soil

Model Soft Soil merupakan advanced model yang dapat digunakan untuk memodelkan jenis perilaku tanah seperti tanah lempung lunak dan juga gambut yang terkonsolidasi secara normal bisa menggunakan pemodelan ini.

\section{METODE PENELITIAN}

Pemodelan dilakukan dengan menggunakan program PLAXIS 2D dengan model axisymmetric. Pemodelan ini dilakukan dengan asumsi tanah lempung lunak yang layak digunakan. Model divariasikan dengan memilih kapastias vakum yang beragam dan juga dengan pemilihan analisis dengan tiga soil model yaitu Mohr Coulomb, Hardening Soil dan Soft Soil. Pemodelan dilakukan untuk mengetahui penurunan konsolidasi dengan menggunakan Prefabricated Vertical Drains (PVD) dan preloading yang dikombinasikan dengan menggunakan vacuum dan tidak menggunakan vacuum. Bagan alir dari penelitian ini ditunjukan Gambar 3. 


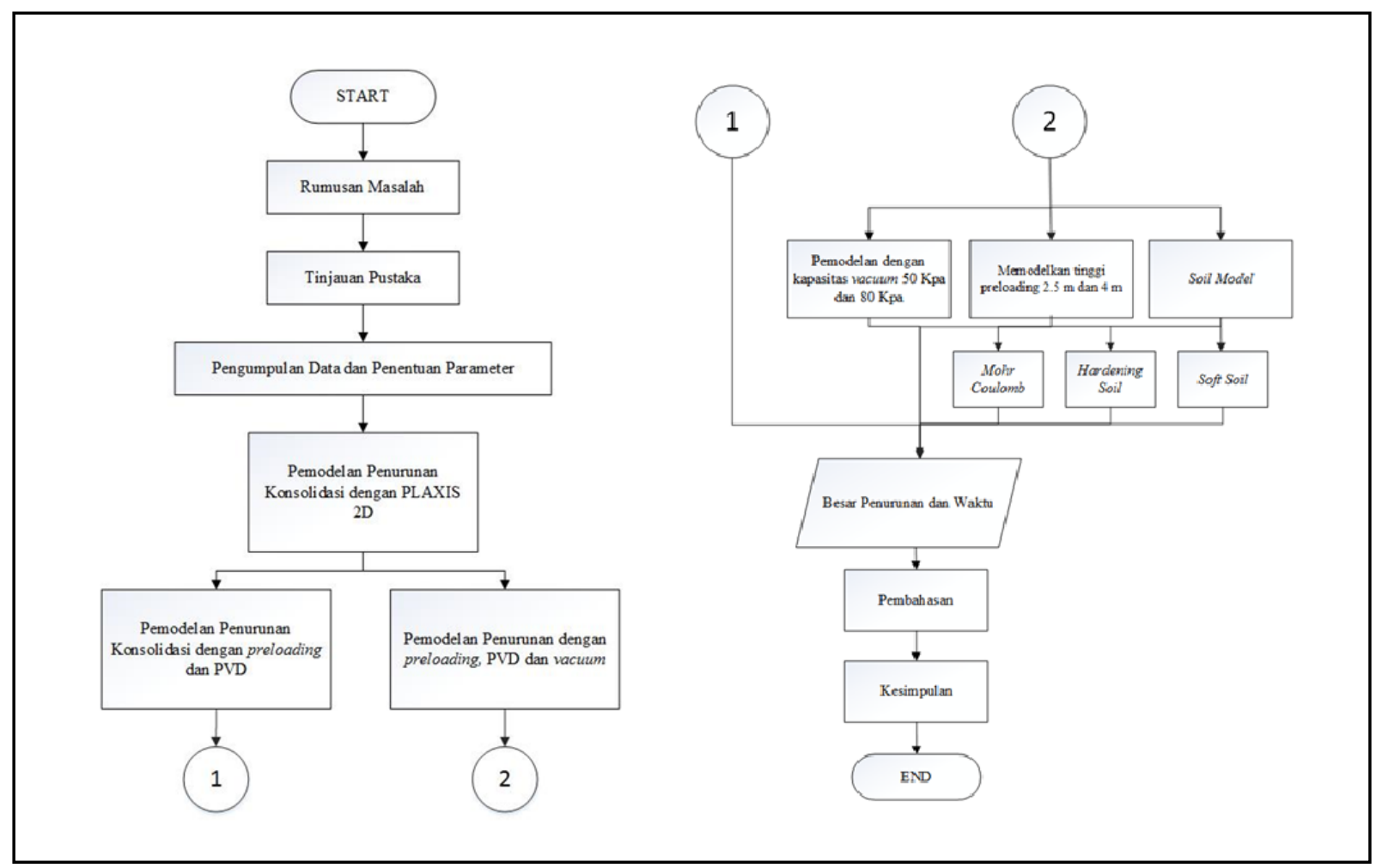

Gambar 3. Bagan alir pemodelan perbaikan tanah menggunakan vacuum consolidation pada tanah lempung lunak dengan program PLAXIS 2D

\section{HASIL PENELITIAN DAN PEMBAHASAN}

\subsection{Pemodelan}

Pemodelan dilanalisis dengan mengunakan tiga soil model yaitu Mohr Coulomb, Hardening Soil dan Soft Soil. Berikut parameter tanah yang digunakan pada Pemodelan PLAXIS 2D pada Tabel 1 menyajikan parameter tanah lempung lunak dan timbunan.

Tabel 1. Parameter Model Mohr Coulomb

\begin{tabular}{|c|c|c|c|c|c|c|c|c|}
\hline & $\begin{array}{c}\text { Ketebalan } \\
{[\mathrm{m}]}\end{array}$ & $\begin{array}{c}\gamma_{s a t} \\
{\left[\mathrm{kN} / \mathrm{m}^{3}\right]}\end{array}$ & $\begin{array}{c}\gamma_{\text {unsat }} \\
{\left[\mathrm{kN} / \mathrm{m}^{3}\right]}\end{array}$ & $\begin{array}{c}E^{\prime} \\
{\left[\mathrm{kN} / \mathrm{m}^{3}\right]}\end{array}$ & $v$ & $\begin{array}{c}c \\
{\left[\mathrm{kNm}^{2}\right]}\end{array}$ & $\begin{array}{c}\varphi \\
{[\circ]}\end{array}$ & $\begin{array}{c}k_{h}=k_{v} \\
\text { [m/hari] }\end{array}$ \\
\hline Lempung Lunak & 10 & 16 & 16 & 1.100 & 0,2 & 12 & 24 & $0,16 * 10^{-3}$ \\
\hline Timbunan & 3 & 20 & 20 & 22.000 & 0,2 & 10 & 30 & $8,64 * 10^{-3}$ \\
\hline
\end{tabular}

Pada soil model MC (Mohr Coulomb) nilai $E$ bisa langsung digunakan sesuai data dengan di lapangan namun berbeda dengan soil model HS (Hardening Soil) diperlukan adanya konversi parameter. Konversi parameter ini di lakukan untuk mengetahui nilai $E_{50}^{r e f}, E_{o e d}^{r e f}$, dan $E_{u r}^{r e f}$ yang akan digunakan dalam parameter HS model. Konversi dilakukan dengan pengujian Oedometer yang terdapat di PLAXIS 2D. Trial and error dilakukan dengan cara mencobacoba nilai $E$ untuk parameter HS model hingga diperoleh grafik pengujian yang dianggap serupa. Setelah melakukan tahap trial and error, diperoleh hasil pengujian Oedometer. Berikut ini merupakan hasil dari pengujian Oedometer ditunjukan Gambar 4. 


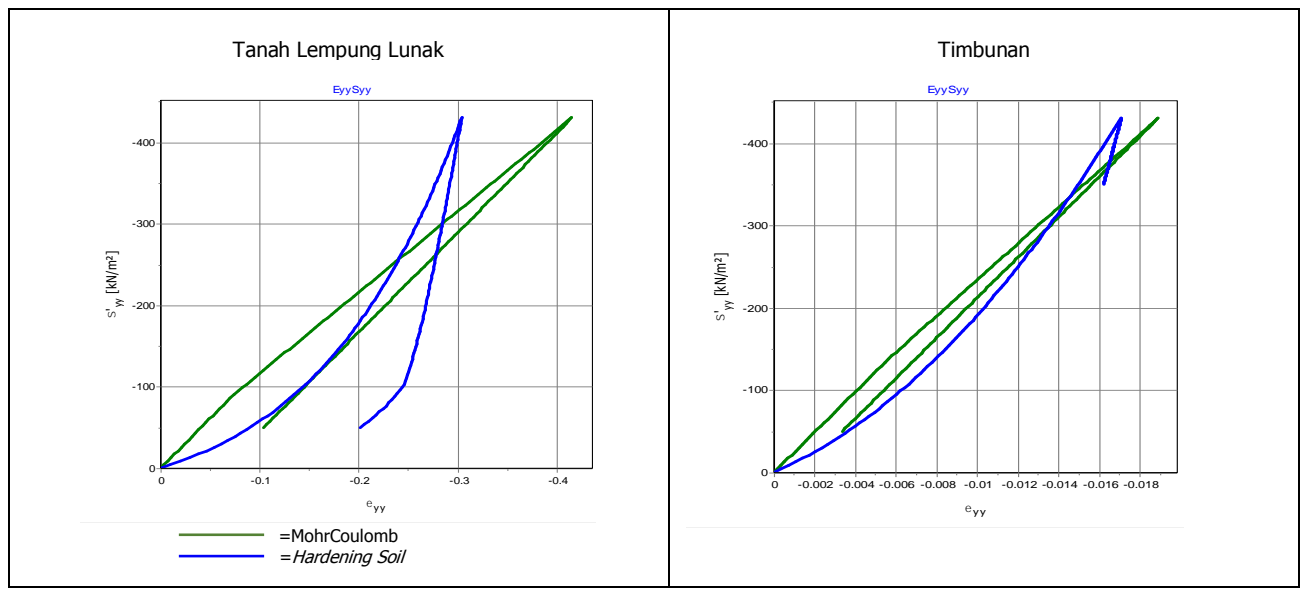

Gambar 4. Grafik parameter hasil soil test dengan oedometer

Berdasarkan hasil tria/ and error diperoleh nilai $E_{\text {oed }}^{\text {ref }}$ untuk setiap lapisan tanah seperti yang ditampilkan pada Tabel $\mathbf{2}$.

Tabel 2. Parameter Hardening Soil Model

\begin{tabular}{cccccc}
\hline & $\begin{array}{c}\text { Ketebalan } \\
{[\mathbf{m}]}\end{array}$ & $\begin{array}{c}\gamma_{\text {sat }} / \gamma_{\text {unsat }} \\
{\left[\mathbf{k N} / \mathbf{m}^{3}\right]}\end{array}$ & $\begin{array}{c}\boldsymbol{E}_{\mathbf{5 0}}^{\text {ref }}=\boldsymbol{E}_{\text {oed }}^{\text {ref }} \\
{\left[\mathbf{k N} / \mathbf{m}^{2}\right]}\end{array}$ & $\begin{array}{c}\boldsymbol{E}_{\text {ur }}^{\text {ref }} \\
{\left[\mathbf{k N} / \mathbf{m}^{2}\right]}\end{array}$ & $\begin{array}{c}\boldsymbol{E} \\
{[\text { power] }}\end{array}$ \\
\hline Lempung Lunak & 10 & $16 / 16$ & 3 & 1,1 & 0,9 \\
\hline Timbunan & 3 & $20 / 20$ & 60 & 22 & 0,5 \\
\hline
\end{tabular}

Tabel 2. Parameter Hardening Soil Model (lanjutan)

\begin{tabular}{cccccccc}
\hline & $\begin{array}{c}\boldsymbol{c}_{r e f}^{\prime} \\
{\left[\mathbf{k N} / \mathbf{m}^{2}\right]}\end{array}$ & $\begin{array}{c}\boldsymbol{\varphi} \\
{\left[{ }^{\circ}\right]}\end{array}$ & $\boldsymbol{v}_{\boldsymbol{u r}}^{\prime}$ & $\begin{array}{c}\boldsymbol{P}_{\text {ref }} \\
{\left[\mathbf{k N} / \mathbf{m}^{\mathbf{2}}\right]}\end{array}$ & $\boldsymbol{K}_{\boldsymbol{n} \boldsymbol{c}}^{\mathbf{0}}$ & $\boldsymbol{R f}$ & $\boldsymbol{k}_{\boldsymbol{h}}=\boldsymbol{k}_{\boldsymbol{v}}$ \\
\hline Lempung Lunak & 12 & 24 & 12 & 24 & 0,59 & 0,9 & $0,16 * 10^{-3}$ \\
\hline Timbunan & 10 & 30 & 10 & 30 & 0,5 & 0,9 & $8,64 * 10^{-3}$ \\
\hline
\end{tabular}

Soil model selanjutnya adalah SS model. Sama dengan HS model, pada SS model perlu adanya konversi parameter sebelum melakukan pemodelan. Ada dua parameter utama yang harus dicari sebelum melakukan pemodelan dengan SS model, yaitu $\lambda^{*}$ dan $K^{*}$. Berikut data yang digunakan untuk mencari nilai $\lambda^{*}$ dan $K^{*}$ :

$$
\begin{aligned}
& c_{c}=0,345 \\
& c_{s}=0,1035 \\
& e=0,5
\end{aligned}
$$

Perhitungan nilai $\lambda^{*}$ dan $K^{*}$ :

$$
\begin{gathered}
\lambda^{*}=\frac{c_{c}}{2,3(1+e)}=\frac{0,345}{2,3(1+0,5)}=0,1 \\
K^{*}=\frac{2 c_{S}}{2.3(1+e)}=\frac{2 x 0.1035}{2.3(1+0.5)}=0,06
\end{gathered}
$$


Tabel 3. Parameter Tanah dan Timbunan Soft Soil

\begin{tabular}{|c|c|c|c|c|c|c|c|c|c|}
\hline & $\begin{array}{c}\text { Ketebalan } \\
{[\mathrm{m}]}\end{array}$ & $\begin{array}{l}\gamma_{\text {sat }} / \gamma_{\text {unsat }} \\
{\left[\mathbf{k N} / \mathbf{m}^{3}\right]}\end{array}$ & $\begin{array}{c}c^{\prime} \\
{\left[k N / m^{2}\right]}\end{array}$ & $\begin{array}{c}\varphi \\
{\left[{ }^{\circ}\right]}\end{array}$ & $v_{u r}^{\prime}$ & $K_{n c}^{0}$ & $\lambda^{*}$ & $\boldsymbol{K}^{*}$ & $\begin{array}{r}k_{h}=k_{v} \\
{[\mathrm{~m} / \text { hari] }}\end{array}$ \\
\hline Lempung Lunak & 10 & $16 / 16$ & 12 & 24 & 0,2 & 0,59 & 0,1 & 0,6 & $0,16 * 10^{-3}$ \\
\hline Timbunan & 3 & $20 / 20$ & 10 & 30 & 0,2 & 0,5 & $5 * 10^{-3}$ & $3 * 10^{-3}$ & $8,64 * 10^{-3}$ \\
\hline
\end{tabular}

Tahapan pemodelan yang dilakukan pada PLAXIS 2D ditunjukan pada Tabel 4 yang menunjukan model dengan mevariasikan tanpa vakum dan Tabel $\mathbf{5}$ menunjukan model dengan dengan dikombinasikan dengan vakum.

Table 4. Tahapan Pekerjaan dalam Pemodelan PLAXIS 2D Tanpa Vakum

\begin{tabular}{ccc}
\hline No & Tahapan Pekerjaan & Waktu Pekerjaan \\
\hline 1 & Tanah Asli & - \\
\hline 2 & Pemasangan $P V D$ & 5 hari \\
\hline 3 & Timbunan Layer 1 & 5 hari \\
\hline 4 & Timbunan Layer 2 & 5 hari \\
\hline 5 & Timbunan Layer 3 & 5 hari \\
\hline 6 & Konsolidasi $90 \%$ & Sampai konsolidasi $90 \%$ \\
\hline
\end{tabular}

Table 5. Tahapan Pekerjaan dalam Pemodelan PLAXIS 2D Dengan Vakum

\begin{tabular}{ccc}
\hline No & Tahapan Pekerjaan & Waktu Pekerjaan \\
\hline 1 & Tanah Asli & - \\
\hline 2 & Pemasangan $P V D$ & 5 hari \\
\hline 3 & Timbunan Layer 1 & 5 hari \\
\hline 4 & Vakum 1 & 5 hari \\
\hline 5 & Vakum 2 & 5 hari \\
\hline 6 & Vakum 3 & 5 hari \\
\hline 7 & Konsolidasi $90 \%$ & Sampai konsolidasi $90 \%$ \\
\hline
\end{tabular}

\subsection{Hasil Analisis}

Hasil analisis dari pemodelan yang dilakukan pada PLAXIS 2D disajikan pada gambar berikut. Hasil yang didapatkan adalah perubahan tekanan air pori dari setiap tahapan pemodelan pekerjaan mulai dari pemasangan selimut pasir hingga konsolidasi $90 \%$.

\section{A. Pemodelan Mohr Coulomb}

Hasil analisis yang didapatkan dari soil model Mohr Coulomb dengan model Single Drainage ditunjukan pada Gambar 5 dan Gambar 6.

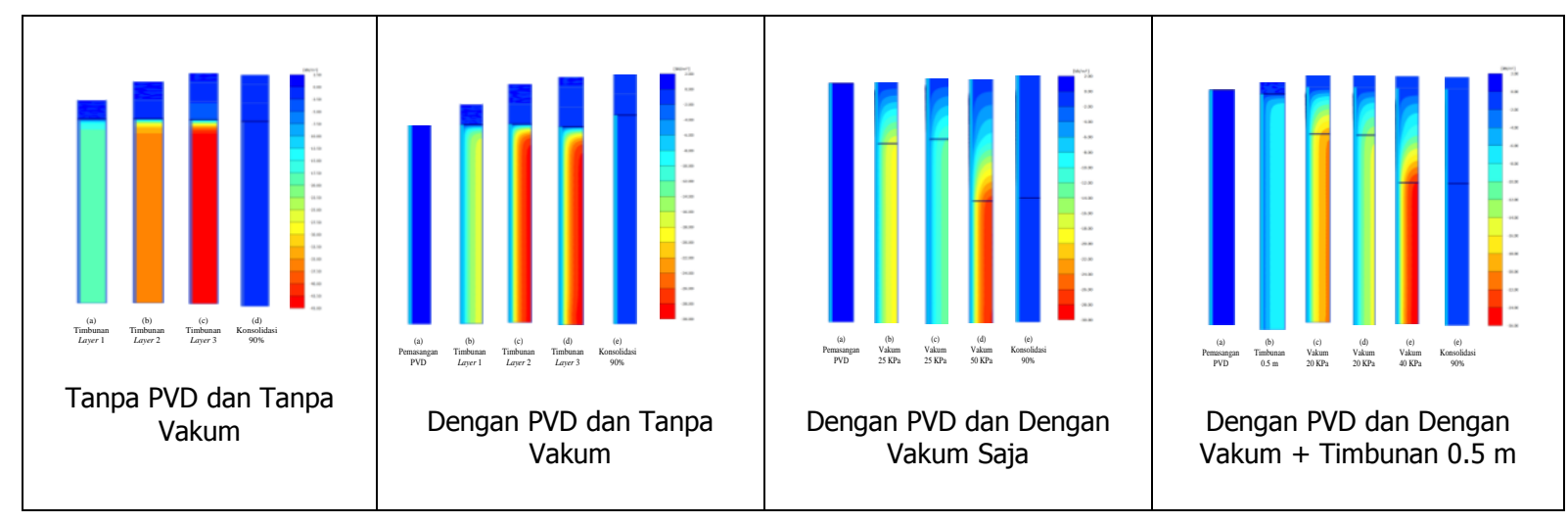

Gambar 5. Tekanan air pori ekses dengan soil mode/ Mohr Coulomb 
Pada Gambar 5 menunjukan perubahan tekanan air pori dari setiap tahapan pemodelan pada kondisi vakum dengan tekanan $50 \mathrm{KPa}$, pekerjaan mulai dari pemasangan PVD hingga konsolidasi $90 \%$. Hasil analisis untuk model Mohr Coulomb (single drainage) dengan kondisi valum 50 KPa ditunjukan pada Gambar 6.

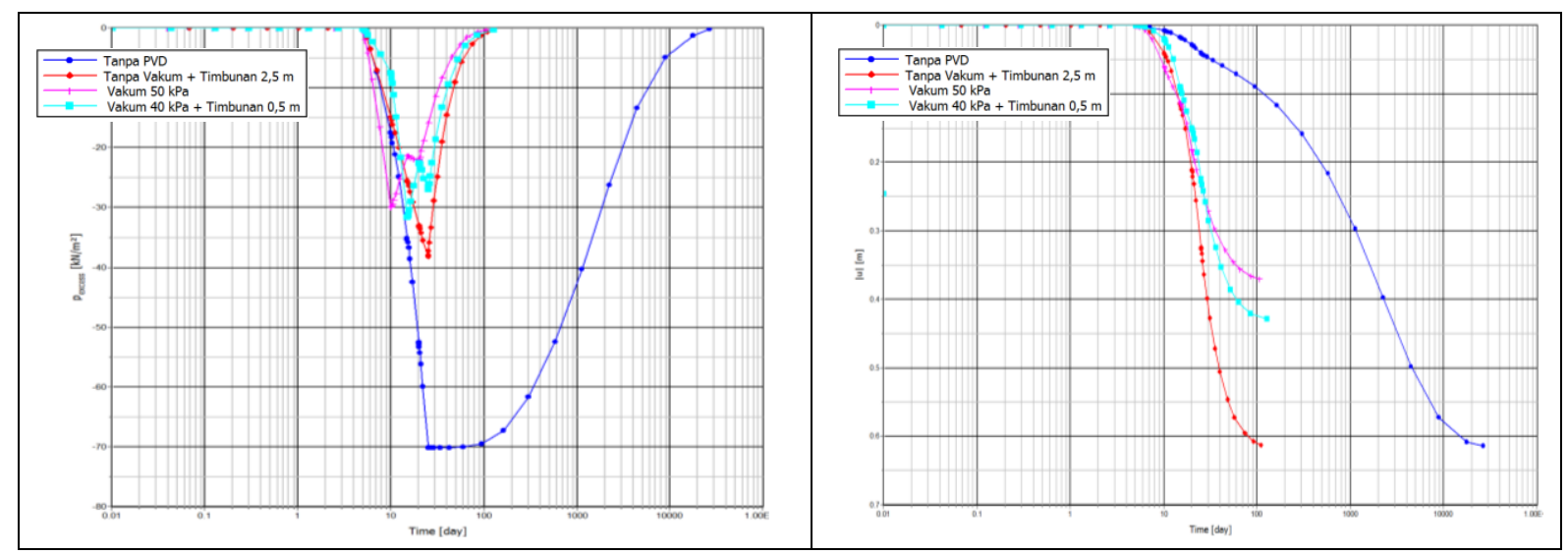

Gambar 6. Hasil analisis soil mode/ Mohr Coulomb (Single Drainage)

Hasil analisis untuk model Mohr Coulomb (single drainage ) dengan kondisi valum $80 \mathrm{KPa}$ ditunjukan pada Gambar 7.

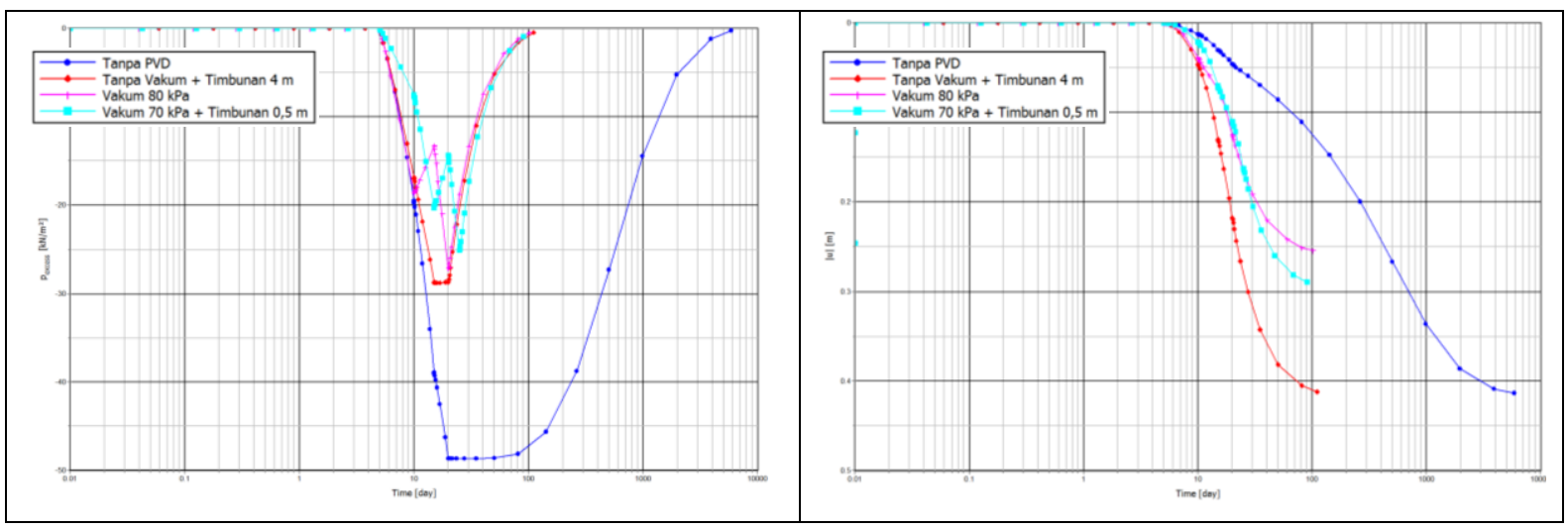

Gambar 7. Hasil analisis soil mode/ Mohr Coulomb (Single Drainage)

Hasil analisis soil mode/ mohr Coulomb dengan kondisi single drainage dan double drainage memiliki perbedaan yang cukup signifikan namun dari hasil analisis menunjukan bahwa hasil dengan kondisi single drainage kombinasi Tanpa PVD + Timbunan 4 m memiliki nilai penurunan yang terbesar, ditunjukan pada Tabel $\mathbf{6}$ untuk nilai konsolidasi.

Tabel 6. Rekapitulasi Penurunan Mohr Coulomb Model

\begin{tabular}{ccccc}
\hline \multirow{2}{*}{ Kondisi } & \multicolumn{2}{c}{ Single Drainage } & \multicolumn{2}{c}{ Double Drainage } \\
\cline { 2 - 5 } & $\begin{array}{c}\text { Waktu } \\
\text { (hari) }\end{array}$ & $\begin{array}{c}\text { Penurunan } \\
(\mathbf{m})\end{array}$ & $\begin{array}{c}\text { Waktu } \\
\text { (hari) }\end{array}$ & $\begin{array}{c}\text { Penurunan } \\
(\mathbf{m})\end{array}$ \\
\hline Tanpa PVD + Timbunan 2,5 m & 23.343 & 0,413 & 5.851 & 0,414 \\
\hline Dengan PVD + Timbunan 2,5 m & 111 & 0,411 & 111 & 0,412 \\
\hline Vakum 50 kPa & 142 & 0,277 & 102 & 0,255 \\
\hline Timbunan 0,5 m + Vakum 40 kPa & 112 & 0,310 & 91 & 0,289 \\
\hline
\end{tabular}


Tabel 6. Rekapitulasi Penurunan Mohr Coulomb Model (lanjutan)

\begin{tabular}{ccccc}
\hline \multirow{2}{*}{ Kondisi } & \multicolumn{2}{c}{ Single Drainage } & \multicolumn{2}{c}{ Double Drainage } \\
\cline { 2 - 5 } & $\begin{array}{c}\text { Waktu } \\
\text { (hari) }\end{array}$ & $\begin{array}{c}\text { Penurunan } \\
\mathbf{( m )}\end{array}$ & $\begin{array}{c}\text { Waktu } \\
\text { (hari) }\end{array}$ & $\begin{array}{c}\text { Penurunan } \\
(\mathbf{m})\end{array}$ \\
\hline Tanpa PVD + Timbunan 4 m & 17.757 & 0,608 & 4.874 & 0,614 \\
\hline Dengan PVD + Timbunan 4 m & 110 & 0,612 & 142 & 0,615 \\
\hline Vakum 80 kPa & 117 & 0,370 & 122 & 0,334 \\
\hline Timbunan 0,5 m + Vakum 70 kPa & 112 & 0,427 & 156 & 0,397 \\
\hline
\end{tabular}

\section{B. Pemodelan Hardening Soil}

Hasil analisis yang didapatkan dari soil model Hardening Soil dengan model Single Drain ditunjukan pada Gambar 8 dan Gambar 9.

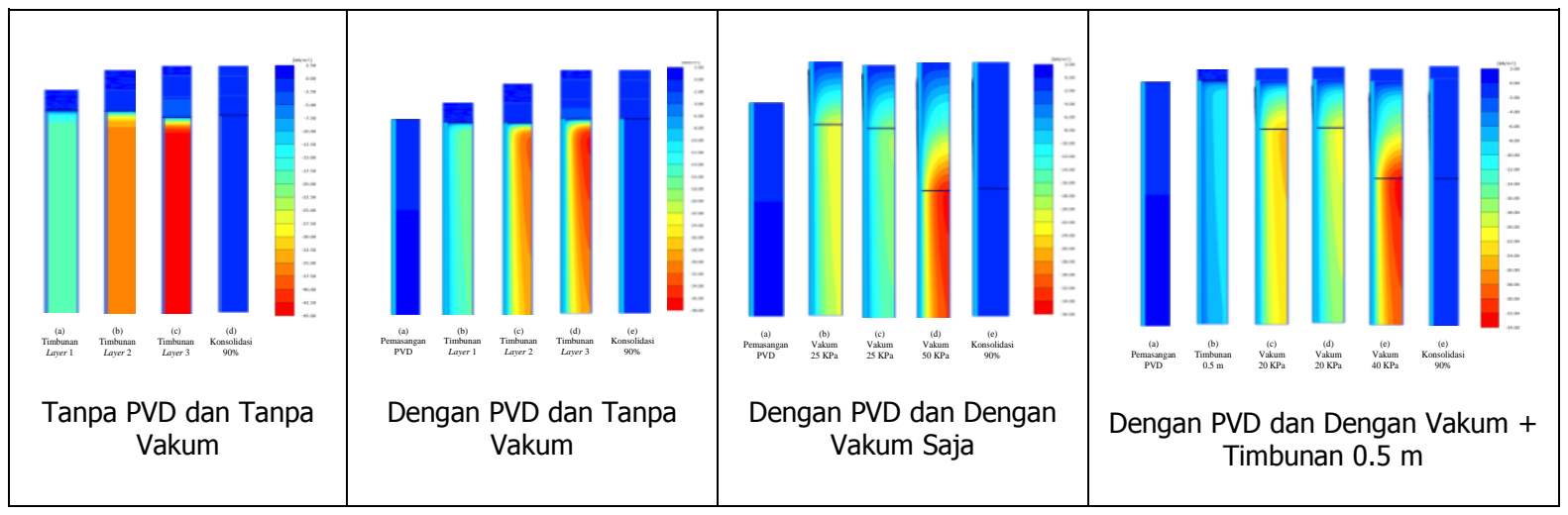

Gambar 8. Tekanan air pori ekses dengan soil model Hardening Soil

Pada Gambar 8 menunjukan perubahan tekanan air pori dari setiap tahapan pemodelan pada kondisi vakum dengan tekanan $50 \mathrm{KPa}$, pekerjaan mulai dari pemasangan PVD hingga konsolidasi $90 \%$. Hasil analisis untuk model Hardening Soil (single drainage) dengan kondisi valum $50 \mathrm{KPa}$ ditunjukan pada Gambar 9.

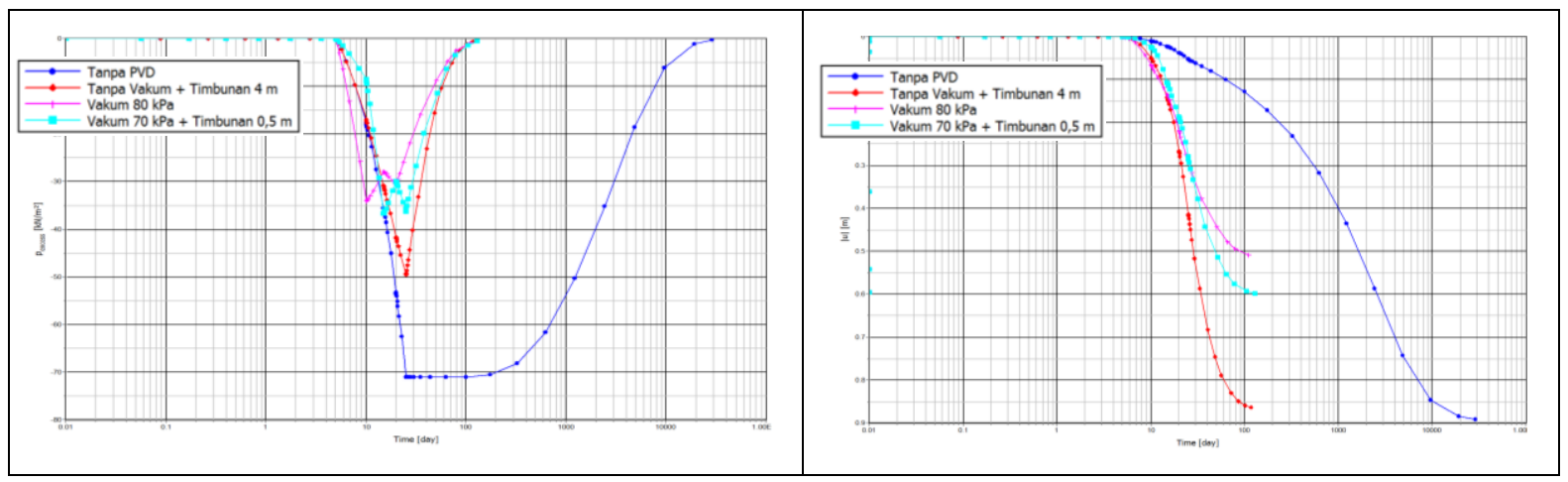

Gambar 9. Hasil analisis soil model Hardening Soil (Single Drainage)

Hasil analisis untuk model Hardening Soil (single drainage) dengan kondisi valum $80 \mathrm{KPa}$ ditunjukan pada Gambar 10. 

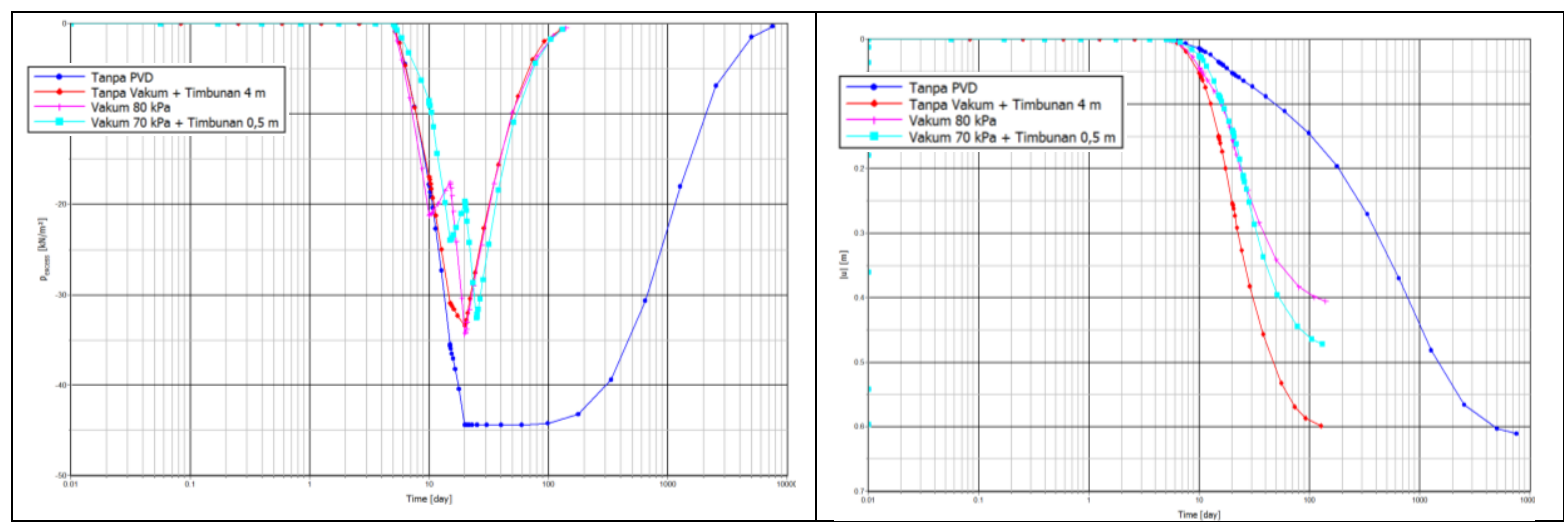

Gambar 10. Hasil analisis soil model Hardening Soil (Single Drainage)

Hasil analisis soil model Hardening Soil dengan kondisi single drainage dan double drainage memiliki perbedaan yang cukup signifikan namun dari hasil analisis menunjukan bahwa hasil dengan kondisi single drainage kombinasi Tanpa PVD + Timbunan $4 \mathrm{~m}$ memiliki nilai penurunan yang terbesar, ditunjukan pada Tabel 7 untuk nilai konsolidasi.

Tabel 7. Rekapitulasi Penurunan Hardening Soil Model

\begin{tabular}{ccccc}
\hline \multirow{2}{*}{ Kondisi } & \multicolumn{2}{c}{ Single Drainage } & \multicolumn{2}{c}{ Double Drainage } \\
\cline { 2 - 5 } & $\begin{array}{c}\text { Waktu } \\
\text { (hari) }\end{array}$ & $\begin{array}{c}\text { Penurunan } \\
\mathbf{( m )}\end{array}$ & $\begin{array}{c}\text { Waktu } \\
\text { (hari) }\end{array}$ & $\begin{array}{c}\text { Penurunan } \\
\mathbf{( m )}\end{array}$ \\
\hline Tanpa PVD + Timbunan 2,5 m & 30.159 & 0,612 & 7.554 & 0,619 \\
\hline Dengan PVD + Timbunan 2,5 m & 128 & 0,598 & 128 & 0,598 \\
\hline Vakum 50 kPa & 125 & 0,426 & 140 & 0,405 \\
\hline Timbunan 0,5 m + Vakum 40 kPa & 131 & 0,489 & 131 & 0,472 \\
\hline Tanpa PVD + Timbunan 4 m & 28.769 & 0,887 & 6.015 & 0,887 \\
\hline Dengan PVD + Timbunan 4 m & 118 & 0,864 & 124 & 0,865 \\
\hline Vakum 80 kPa & 110 & 0,507 & 125 & 0,477 \\
\hline Timbunan 0,5 m + Vakum 70 kPa & 131 & 0,598 & 144 & 0,572 \\
\hline
\end{tabular}

\section{Pemodelan Soft Soil}

Hasil analisis yang didapatkan dari soil model Soft Soil dengan model Single Drain ditunjukan pada Gambar 11 dan Gambar 12.

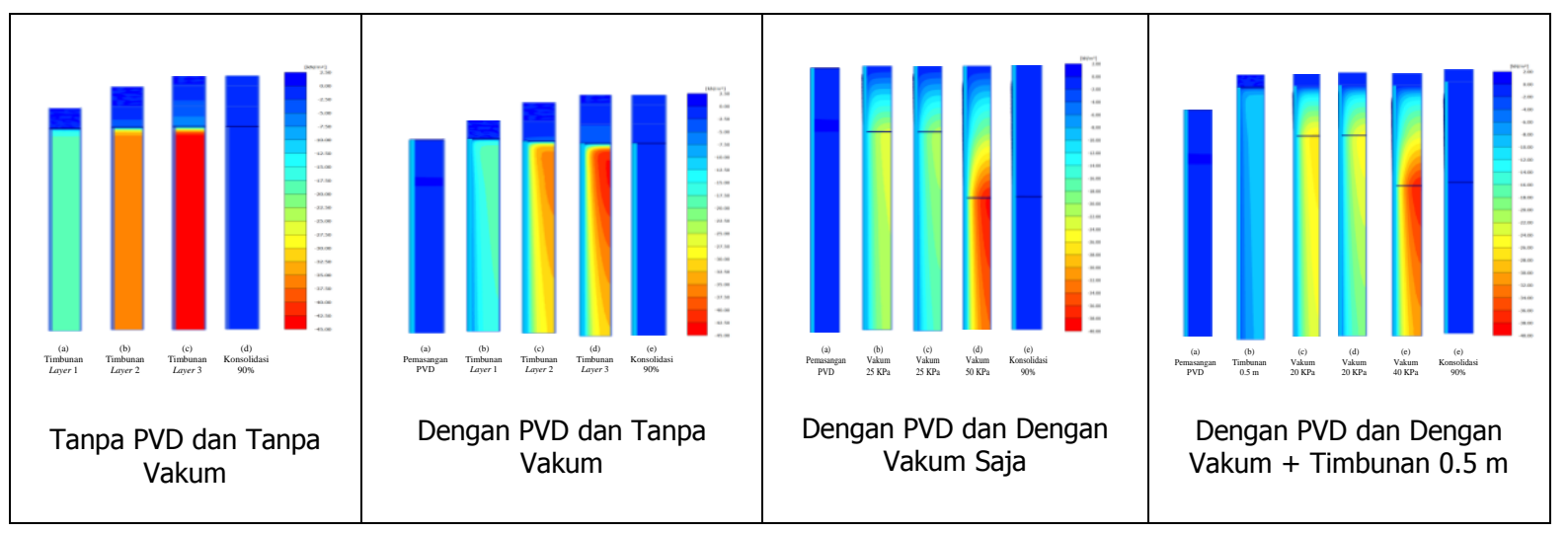

Gambar 11. Tekanan air pori ekses dengan soil model Soft Soil 
Pada Gambar 10 menunjukan perubahan tekanan air pori dari setiap tahapan pemodelan pada kondisi vakum dengan tekanan $50 \mathrm{KPa}$, pekerjaan mulai dari pemasangan PVD hingga konsolidasi $90 \%$. Hasil analisis untuk model Soft Soil (single drainage) dengan kondisi valum $50 \mathrm{KPa}$ ditunjukan pada Gambar 11.

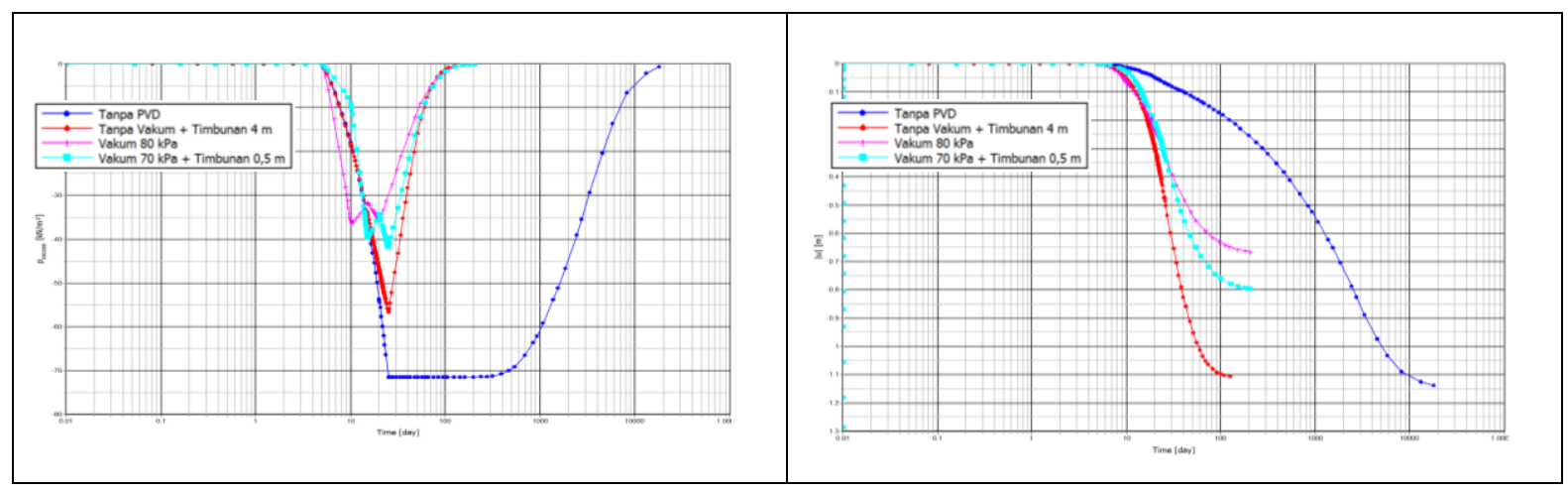

Gambar 12. Hasil analisis soil model Soft Soil (single drainage)

Hasil analisis untuk model Soft Soil (single drainage) dengan kondisi valum $80 \mathrm{KPa}$ ditunjukan pada Gambar 13.

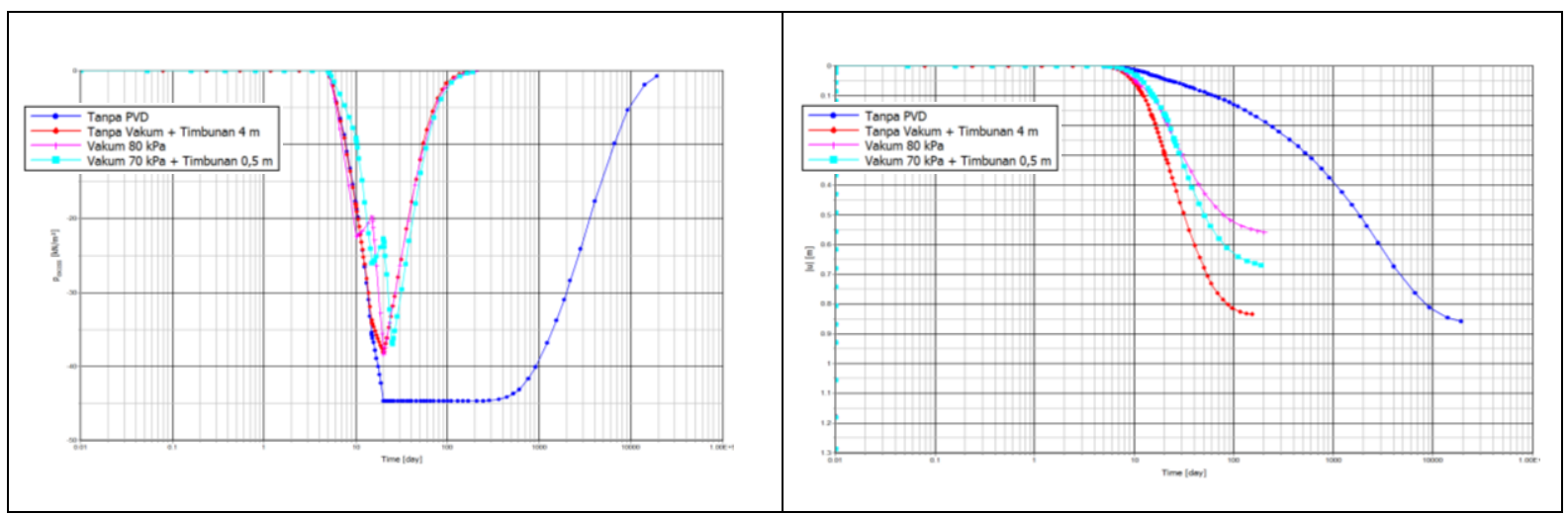

Gambar 13. Hasil analisis soil model Soft Soil (Double Drain)

Hasil analisis soil model Soft Soil dengan kondisi single drainage dan double drainage memiliki perbedaan yang cukup signifikan namun dari hasil analisis menunjukan bahwa hasil dengan kondisi single drainage kombinasi Tanpa PVD + Timbunan $4 \mathrm{~m}$ memiliki nilai penurunan yang terbesar, ditunjukan pada Tabel 8 untuk nilai konsolidasi.

Tabel 8. Rekapitulasi Penurunan Model Soft Soil

\begin{tabular}{ccccc}
\hline \multirow{2}{*}{ Kondisi } & \multicolumn{2}{c}{ Single Drainage } & \multicolumn{2}{c}{ Double Drainage } \\
\cline { 2 - 5 } & $\begin{array}{c}\text { Waktu } \\
\text { (hari) }\end{array}$ & $\begin{array}{c}\text { Penurunan } \\
\mathbf{( m )}\end{array}$ & $\begin{array}{c}\text { Waktu } \\
\text { (hari) }\end{array}$ & $\begin{array}{c}\text { Penurunan } \\
(\mathbf{m})\end{array}$ \\
\hline Tanpa PVD + Timbunan 2,5 m & 19.127 & 0,858 & 19.127 & 0,858 \\
\hline Dengan PVD + Timbunan 2,5 m & 149 & 0,834 & 153 & 0,834 \\
\hline Vakum 50 kPa & 192 & 0,580 & 202 & 0,557 \\
\hline Timbunan 0,5 m + Vakum 40 kPa & 192 & 0,686 & 189 & 0,668 \\
\hline Tanpa PVD + Timbunan 4 m & 17.867 & 1,137 & 17.867 & 1,137 \\
\hline Dengan PVD + Timbunan 4 m & 125 & 1,106 & 128 & 1,107 \\
\hline Vakum 80 kPa & 206 & 0,664 & 201 & 0,632 \\
\hline Timbunan 0,5 m + Vakum 70 kPa & 193 & 0,795 & 200 & 0,767 \\
\hline
\end{tabular}




\section{SIMPULAN}

Berdasarkan hasil penelitian yang telah dilakukan dapat ditarik simpulan sebagai berikut:

1. Pengaruh kondisi single drainage dan double drainage tidak berbeda secara signifikan. Pada soil model Soft Soil penurunan dan waktu penurunan antara single drain dan double drainage menghasilkan nilai yang hampir sama.

2. Soil Model Soft Soil menghasilkan nilai penurunan yang paling besar dibandingkan dengan soil model Mohr Coulomb dan Hardening Soil. Sedangkan soil model Mohr Coulomb menghasilkan nilai penurunan yang paling kecil deibandingkan dengan kedua soil model yang digunakan.

3. Kapasitas vakum mempengaruhi penurunan, semakin besar kapasitas vakum semakin besar juga penurunan.

\section{DAFTAR RUJUKAN}

Dam, L. T. K, Sandanbata, I., \& Kimura, M. (2006). Vacuum Consolidation Method Worldwide Practice and the Latest Improvement in Japan. Annual Report of Hazama, 12.

Das, B. M. (2010). Principles of Geotechnical Engineering. USA: Cengage Learning.

Ikhya, I., \& Schweiger, H. (2012). Numerical Modeling of Floating Prefabricated Vertical Drains in Layered Soil. Acta Geotechnica Slovenica, 2.

Indraratna, B., Rujikiatkamjorn, \& Kelly, R. (2009). Modelling of combined vacuum and surcharge preloading with vertical drains. Procedings of 17th International Conference on Soil Mechanics and Geotechnical Engineering (pp. 2204-2207). Netherlands: IOS Press.

Indraratna, B., Rujikiatkamjorn, C., V Wijeyakulasuriya, G McIntosch, \& R Kelly. (2010). Soft soil improved by prefabricated vertical drains: performance and prediction. Symposium on New Techniques for Design and Construction in Soft Clays (pp. 227246). Brazil: Officna de Textos. 